\title{
ЖИЛИЩА ВАРФОЛОМЕЕВСКОЙ НЕОЛИТИЧЕСКОЙ СТОЯНКИ
}

\author{
(C) 2021 А.И. Юдин
}

Научно-исследовательский центр по сохранению культурного наследия, г.Саратов

Статья поступила в редакцию 01.10.2021

\begin{abstract}
Статья посвящена рассмотрению характера домостроительства на Варфоломеевской стоянке орловской неолитической культуры степного Поволжья. Наиболее полные данные получены при раскопках Варфоломеевской стоянки (конец VII-VI тыс. до н.э.) на р. Малый Узень. Более поздние жилые постройки перекрывали и повреждали ранние, но сопоставление планиграфии и стратиграфии дало возможность распределить их по хронологическим горизонтам и реконструировать основные характерные черты неолитических построек. Жилища представлены полуземлянками крупных размеров с несколькими очагами, хозяйственными ямами вдоль стен котлованов, расположением полов на разных уровнях, плотной застройкой на территории стоянки. Жилища функционировали на протяжении длительного времени. Это подтверждается долговременными очагами с золистыми напластованиями более одного метра на обоих памятниках и следами ремонта опорных столбов на Варфоломеевской стоянке. Установлено, что на всех этапах орловской культуры существовала единая устойчивая традиция домостроительства.

Ключевые слова: неолит, орловская культура, жилища, полуземлянка, очаг.
\end{abstract}

DOI: 10.37313/2658-4816-2021-3-4-115-131

K настоящему времени наиболее полная, но далеко не исчерпывающая информация о жилищах орловской неолитической культуры продолжает базироваться на материалах раскопок Варфоломеевской стоянки, расположенной в степном Заволжье (Саратовская область) и исследовавшейся в 1987-1990 и 1996 гг. Всего на стоянке вскрыто свыше 400 кв. м культурного слоя, включающего четыре литологических горизонта, отражающих все этапы развития орловской культуры (посл. четв. VII тыс до н.э. - VI тыс. до н.э.) ${ }^{1}$. Время существования стоянки определено серией из 36 радиоуглеродных дат, полученных в лабораториях Санкт-Петербурга, Москвы, Киева, Познани и Упсалы ${ }^{2}$.

Тип жилища является одним из важнейших признаков, характеризующих археологическую культуру, в том числе и неолитическую. На эпонимном памятнике орловской неолитической культуры Нижнего Повол-

Юдин Александр Иванович, доктор исторических наук, заместитель директора по научной работе. E-mail: aleyudin@yandex.ru жья в свое время был получен выразительный комплекс керамики, но информация о характере жилища по результатам раскопок сохранившегося участка культурного слоя ограничена, так как большая часть постройки разрушена балкой. Выявлен котлован полуземлянки глубиной 0,6 м, ближе к середине полуземлянки отмечено небольшое очажное пятно (уголь, пепел, прокал земли) толщиной 10 см, две столбовые ямки с внешней стороны котлована. Предполагается прямоугольная форма жилища длиной 6 м с входом примерно 2 м длиной ${ }^{3}$.

Намного больше информации о характере неолитических жилищ получено по итогам раскопок Варфоломеевской стоянки. Практически вся исследованная площадь Варфоломеевской стоянки занята котлованами построек и, судя по большому количеству очагов, именно жилых построек (рис. 1). С одной стороны, это позволило детально исследовать ряд конструктивных особенностей неолитических построек. Но, с другой стороны, это значительно затрудняет детальное воссоздание общего облика жилища, 
так как котлованы более ранних построек не только перекрываются позднейшими, но и прорезаются ими. Кроме того, исследовался прибрежный участок памятника, интенсивно размываемый в то время водами Варфоломеевского водохранилища на р.Малый Узень, и постройки были частично уничтожены береговой осыпью.

Жилые постройки различной степени сохранности встречены в трех нижних неолитических слоях. Поскольку на стоянке представлено эволюционное развитие одной культуры, способ устройства жилищ остается одинаковым на протяжении всего неолита.

Ниже приводится описание жилищ, сохранившихся наиболее полно, а также отдельных участков жилищ с наиболее интересными конструкциями. Сопоставление планиграфии и стратиграфии (рис. 2) позволило распределить пять выделенных жилищ по трем хронологическим горизонтам. Три жилища относятся к слою 2 А (поздний неолит) и по одному - к слою 2 Б (средний неолит) и слою 3 (ранний неолит).

\section{Постройки слоя 2 А.}

Жилище 1 (рис. $1 ; 2 ; 3,1)$ располагалось по восточной границе раскопа.

С севера и востока котлован жилища ограничен бортами раскопа, поэтому полная ширина и длина не установлены. Максимальная попавшая в раскоп ширина - 2,55 м, длина - 3,65 м. Борта котлована отвесные, высота 0,2-0,45 м. На расстоянии 1,3 м от западного борта котлована и 1,6 м от южного находился очаг овальной в плане формы. Очаг устроен в материковом дне котлована и имел округлое дно. Размеры: $1,05 \mathrm{x0}, 75 \mathrm{~m}$, глубина в материке 0,12 м. Заполнение очага - зола, мелкие угольки и обожженные кости животных. К северному краю очага примыкала ямка диаметром до 0,3 м и глубиной 0,18 м. Еще одна такая же по размерам столбовая ямка была выкопана в северо-западном углу котлована. В 0,4 м к северо-востоку от очага находилась обширная (до 1 м в диаметре) яма глубиной до 0,15 м, заполненная культурным слоем.
Вокруг очага, вдоль стенок и пятнами по дну залегали прослойки красной охры. С запада стенка котлована имеет понижение, которое можно интерпретировать как вход. Это понижение продолжалось за пределами котлована в виде постепенно сужающейся канавки длиной 1,8 м и шириной от 1 м. Заполнение котлована - культурный слой 2 А. Ко времени этого слоя мы можем относить и само жилище.

Скорее всего, этот котлован является только центральной частью жилища, так как с западной стороны в 1,5-2 м проходит высокая материковая стенка, разделяющая два жилища, а к северу дно жилища поднимается уступом и через два метра уходит под стенку котлована. Эта более высокая часть дна котлована также покрыта слоем охры и заглублена в материк на 0,11-0,29 м. В ней были устроены три столбовые ямки - две на краю, примыкающем к пониженной части, и одна у западной стенки котлована. Еще четыре столбовые ямки проходили вдоль стенки котлована с внешней стороны. Охрой были покрыты и участки материка к западу и югу от котлована на протяжении 2,5-3,0 м. Таким образом, можно предполагать общую длину жилища (сохранившуюся) 8,4 м по линии северо-запад - юго-восток. Максимальная ширина жилища в центральной части - 4,6 м. Но следует учесть, что восточная и северная части жилища выходили за пределы раскопа, а южная часть была размыта водохранилищем.

Поскольку со слоем 2А связаны позднейшие постройки, не перекрытые другими напластованиями, они сохранились в наилучшей степени. Еще одна постройка, жилище 2 слоя 2А, располагалась в квадратах 30, 45-54, 63, 64. Здесь также исследована юго-западная часть постройки (рис. 1 ; 3 , 2-4). Котлован центральной части землянки прямоугольной (а возможно, и квадратной) формы имеет следующие размеры. Длина исследованной части по линии северо-восток - юго-запад составляла 5,5 м, по линии северо-запад - юго-восток - 2 м. Глубина котлована в материке 0,65 м в северо-за- 
падном углу, 0,33 м в юго-западном углу и 0,2 м в юго-восточной части. В 1,1 м от западной стенки и на таком же расстоянии от южной в материковом дне сооружен очаг сложной конструкции (рис. 3,4 ).

Очаг округлой в плане формы диаметром 1,1-1,28 м имел плоское дно и покатые стенки. Глубина очага в материке - до 0,33 м. По дну был заполнен слоем золы. С северной стороны к очагу примыкала яма диаметром 0,4 м и глубиной 0,38 м, заполненная культурным слоем. Еще две ямки меньшего диаметра устроены в бортах очага и наклонены к его центру. Эти ямки и очаг были заполнены культурным слоем с сильной примесью золы и чистой золой по дну. K очагу примыкает канавка шириной 0,4 м и глубиной 5 - $10 \mathrm{~cm}$, соединяющая его с двумя ямами (глубина 0,5 и 0,85 м), расширяющимися ко дну. Заполнение ям состояло в основном из золы и древесных угольков. Длина канавки и ям - 1,8 м, а общая длина конструкции с очагом и северной ямой - до 3,3 м. Вероятнее всего, такая конструкция - одно из приспособлений для обогрева жилища, когда угли и зола не выносились сразу за пределы жилья, а ссыпались в приочажные ямы до полного остывания.

Еще две столбовые ямы были сооружены у северного края очага по обе его стороны. Одна из этих ям диаметром 0,3 м и глубиной 0,52 м была перекрыта слоем охры, посыпанной на дно котлована. Причем охра насыпалась по дну несколько раз, следовательно, сама яма относится к начальному этапу функционирования жилища. В 0,7 м к северо-западу от этой ямы находилась еще одна диаметром 0,28-0,38 м и глубиной 0,25 м. Четыре столбовые ямы располагались и по обе стороны канавки, примыкающей к очагу, - три с западной и одна с восточной. Диаметры их 0,25-0,38 м, глубина от 0,14 до 0,38 м. Сложная система ямок проходит вдоль южной стенки котлована, но она относится к более раннему жилищу из слоя 2Б, которая будет описана ниже.

В юго-западном углу котлована был сооружен еще один очаг округлой формы диа- метром 0,7 м и глубиной до 0,1 м от уровня дна котлована. Очаг был наполовину врезан в угол котлована, в этом месте его глубина от верхнего уровня стенки составляла 0,42 м. Дно очага было заполнено слоем золы, в которой встречались фрагменты керамики и кремни.

Две столбовые ямки проходили по краю стенки котлована с западной стороны. Здесь, как и в предыдущем случае, котлован, вероятно, являлся центральной, наиболее заглубленной частью постройки. С запада и юга к котловану примыкает более высокая часть дна жилища. Ширина этой части составляла 1,4-2,0 м в западной части и до 1,7 м в южной. Эта часть была заглублена в материк от 0,4 м в северной части до 0,7 м. в юго-западной, где сохранился материковый останец, отделяющий эту постройку от соседних с западной и южной сторон (рис. 3, 3). Это один из немногих участков на поселении, где можно установить максимальную глубину постройки в материке. Если брать за верхнюю точку отсчета высоту материкового останца, являющегося западной стенкой котлована жилища, а за нижнюю - дно наиболее заглубленной части котлована в центральной части, то общая глубина составляет 0,94-1,02 м.

В этой части жилища также в юго-западном углу был устроен еще один очаг диаметром 0,55-0,6 м и глубиной 0,13 м, заполненный золой. К югу и востоку от очага были расположены две хозяйственные ямы. В северо-западной материковой части был устроен выход в северном направлении в виде изогнутого коридора шириной 0,5-0,6 м.

Стратиграфические разрезы показывают заполнение верхней и нижней части котлована культурным слоем 2А. Оба уровня пола жилища посыпаны несколькими слоями охры. В данном случае картина полностью аналогична той, что мы видели и в предыдущем жилище на восточной границе раскопа.

Общая исследованная длина котлована по линии северо-запад - юго-восток составляет около 7 м, по линии юго-запад - северо-восток около 7-8 метров. В данном случае оста- 
лись неисследованными участки жилища с северной и восточной сторон. Если предположительно считать центральный очаг центром жилища, то тогда его полные размеры будут составлять минимум 8х9-10 м.

В средней части заполнения котлована, над его центральным, наиболее глубоким участком залегала линза светлого материкового суглинка, перекрытая сверху линзой культурного слоя с обильной примесью золы. Возможно, это остатки от земляного перекрытия крыши (рис. 7, 1).

Западнее жилища 2, отделенная от него материковым останцем, располагалась еще одна постройка, также относящаяся к слою 2 А (рис. $1 ; 4,1,2$ ). В жилище 3 совершенно точно установлено, что полы располагались на двух уровнях по золистому шлейфу по дну котлована, переходящему из верхнего уровня в нижний. От нижней части котлована сохранился только северо-восточный угол, остальная часть уничтожена водами водохранилища. Сохранившаяся длина стенки нижнего котлована по линии югозапад - северо-восток-восток составляет более 7 метров, длина северо-восточной стенки - около 4,7 метра. К нижнему котловану с северной и восточной сторон примыкает более высокий участок дна постройки. Перепад высот между верхней и нижней частями котлована от 0,1 до 0,48 м. Верхняя часть котлована, в свою очередь, плавно понижается в сторону реки и разделена приблизительно в средней части ступенькой по линии север - юг. Таким образом, западная часть немного (0,1-0,2 м) ниже восточной. C западной и восточной сторон верхний котлован ограничен материковыми выступами. Эта часть жилища заглублена в материк на 0,1-0,15 м. Полные размеры жилища (сохранившаяся часть): с северо-запада на юго-восток - около 9 метров, при этом в северной части раскопа жилище уходит под борт раскопа, а в южной части - размыто водохранилищем; с юго-запада на северовосток - 10,8 м.

Котлованы соединены ступенькой, выполненной в верхнем уровне. Но сразу под ступенькой в материковом дне нижней части жилища была устроена обширная яма $(0,40 x 0,85$ м, глубина 0,6 м от дна нижнего котлована), на дне которой лежал обработанный рог оленя. К этой яме вела еще одна ступенька-яма со стороны нижнего котлована. Создается впечатление, что ступеньки служили не для сообщения между двумя частями жилища, а для удобного доступа к яме с обоих уровней жилища (рис. 4,$1 ; 5,1$ ).

К северу от этой ямы, на верхнем уровне котлована находился очаг овальной в плане формы (1,2х2,4 м), вытянутый по линии север - юг. С восточной стороны очаг ограничен невысокой (в пределах 0,2 м) материковой ступенькой, с запада - описанной выше ямой, полого опускающейся к югу, на дне которой встречались зола и очень мелкие угольки. Это подтверждает одновременность существования очага и ямы. Мощность золистого заполнения очага достигает 0,4 м. В западной половине очага - мощный прокал материковой почвы, достигающий толщины 0,2 м. Зольное заполнение очага насыщено костями животных, в центре очага они сильно обожжены. В заполнении очага также найдены костяная проколка и 9 кремневых отщепов, лежащих компактной кучкой. На краю очага, в южной части, лежал абразивный камень прямоугольной формы из буро-красного песчаника.

В трех метрах восточнее этого очага находился еще один крупный очаг (диаметр до 1,6 м), золистое заполнение которого прослеживалось с глубины 40 см от современной дневной поверхности (-107 см) до самого дна (-170 см). Дно очажной ямы в разрезе полукруглое, с небольшой ступенькой с северной стороны. По уровню материка очаг перекрывался тонким слоем глины.

Рядом с ямой с рогом животного и также под стенкой котлована была устроена еще одна округлая яма диаметром 0,84-0,95 м и глубиной 0,6-0,24 м от дна нижней части котлована (рис. 5, 1). Яма была заполнена культурным слоем, не отличающимся от вышележащего. Весь культурный слой в яме был 
насыщен мелкими обломками костей животных, среди которых были обнаружены:

- ножевидная пластина из серого кремня;

- крупный костяной тупик ${ }^{4}$;

- свыше двух десятков мелких кремневых чешуек у западного края ямы;

- развал круглодонной чаши с накольчатым орнаментом почти в центре ямы ${ }^{5}$;

- несколько десятков таранных костей MPC и передних зубов лошади, в том числе с насечками, в компактной кучке в северозападной части ямы;

- несколько таранных костей МРС и передних зубов лошади с насечками, таранная кость КРС и расколотая трубчатая кость с обработанным концом в южной части ямы.

Еще одна яма под стенкой находилась в северо-восточном углу котлована. Яма расширялась ко дну, образовывая подбой под северную стенку котлована. Диаметр ямы 0,8 м, глубина 0,47 м от уровня дна нижнего котлована. Яма заполнена культурным слоем с фрагментами керамики и костей животных. Найдено сечение пластины и крупный круглый камень на дне подбоя (рис. 5, 2).

К югу от этой ямы находился небольшой очаг овальной формы, и еще один очаг находился еще южнее, но он почти полностью был уничтожен береговой осыпью.

Дно жилища посыпано красной охрой, особенно много ее было в нижнем уровне котлована.

По всей площади жилища распределены столбовые ямки, как у краев котлованов, так и между очагами. Диаметры ямок - 0,150,30 м, глубины от 0,09 м до 0,46 м. Между двумя крупными очагами в северной части жилища компактно на площади $2 \mathrm{x} 2$ м располагалось пять столбовых ямок. В двух случаях ямки были перекрыты слоем охры по дну жилища.

\section{Постройки слоя 2 Б.}

Жилище 4. Сохранился материковый участок, который совершенно точно связывается со слоем 2 Б (рис. 1). Длина западной стенки центрального котлована 4,7 м, северной - 4,4 м, восточной - 4,5 м. Полная длина западной стенки не устанавливается, в пределы раскопа попал ее участок длиной около 9-10 м, южная часть стенки уничтожена береговым обрывом. Восточная стенка устанавливается на протяжении 9-9,5 м, а далее котлован жилища залегал уже в культурном слое, и позднее восточная часть жилища была перекрыта и уничтожена котлованом из слоя 2 А.

Глубина центрального котлована в материке 0,4-0,5 м в северной части. Глубина более высокой части котлована - 0,2-0,3 м (рис. 1).

В заглубленном котловане было два очага - в центре и в юго-западной части, а также ряд столбовых ямок, расположенных по всей площади котлована. Центральный очаг - двойной: два очага (1,5x1,0 м и 1,5х1,3 м) разделены тонкой перемычкой. Стенки плавно понижаются ко дну. Максимальная глубина в материке - 0,24 м. Очаг был заполнен культурным слоем, в котором преобладала зола. Встречались кости животных, орудия из кости, керамика. В центре южной ямы прослежено пятно сильного прокала, а северная часть второй ямы была перекрыта слоем светлого суглинка. Очаг по периметру окружают столбовые ямки 0,1-0,3 м в диаметре и глубиной от 0,06 до 0,45 м. Очаг в югозападной части был своим западным краем немного врезан в стенку котлована. Золистое заполнение очага достигало 0,15 м толщины. В двух метрах к юго-востоку от этого очага, уже на возвышенной части котлована жилища, был сооружен еще один двойной очаг с ямами диаметром 1,1м и 1,3 м. Мощность золистого слоя в ямах и над ними достигала 0,35 м. Между двойным очагом и очагом в стенке зачищено 11 столбовых ямок, в том числе примыкающих к краям очагов.

В северной части под стенкой нижней части котлована была сооружена обширная хозяйственная яма $(1,85 \times 1,1$ м) глубиной 0,25-0,5 м. Еще одна крупная яма с двумя ступеньками глубиной до 0,4 м находилась рядом с двойным южным очагом.

Дно котлована было покрыто слоем красной охры, особенно густо и неоднократно - в заглубленной части. 
Данное жилище интересно тем, что его северо-западный угол сгорел в древности (рис. 5, 3) и по нему стало возможно детально ознакомиться с конструкцией стен. По краю котлована на относительно равных промежутках (через метр-полтора) вкапывались столбы диаметром 20-25 см, между ними - две три жерди толщиной до 10 см. Полученный каркас переплетался тростником и обмазывался глиной. Особенно хорошо конструкция стены была видна по северной стенке жилища. Основание стены залегало на материковом останце (сырцовые блоки?). По краю котлована в нем выкопан ряд столбовых ямок. К югу от них, по внутренней стороне стенки котлована, на ступеньке, заглубленной на 20 см от верха останца, вертикально располагались: слой прокаленной глины (5-7 см), слой мелких углей с хорошо сохранившейся структурой длинных стеблей растений (10 см) и опять слой прокаленной глины (рис. 6, 1, 2). После разборки этих слоев, на ступеньке вырисовались столбовые ямки различного диаметра, заполненные золой. Установлено, что с внутренней стороны стены жилища были окрашены, как и дно котлована, красной или розовой (воздействие огня?) охрой.

Котлован перекрыт линзой светлого материкового суглинка, возможно, происходящего с кровли жилища. Эта линза разделяет культурные слои 2 А и 2 Б. Возможно, жилище продолжалось к северу и востоку за пределами котлована, в части, менее заглубленной в материк. Доказательством этому может служить стратиграфия залегания культурного слоя 2Б, который распространяется к северу и востоку от заполнения котлована и ничем от него не отличается. В таком случае размеры жилища увеличиваются на 2 м к северу (и слой уходит далее под бровку) и на 3-3,5 м к востоку. Далее на восток культурный слой залегает на нижнем слое 3 и восточный край полуземлянки не прослеживается.

\section{Постройки нижнего слоя (слой 3).}

Жилища этого горизонта сохранились плохо, они прорезались более поздними, но на одном участке сохранились не только материковый пол с ямами, но и часть стенок котлована, хотя и на незначительную глубину.

Жилище 5 (рис. 1). Сохранилась северная часть котлована. Длина его с запада на восток составляла около 5,5 м. Длина с севера на юг полностью не устанавливается, так как южная часть жилища разрушена водохранилищем: длина по западной стенке около 3 м, по восточной - не менее 5 м. Глубина котлована - 0,2-0,3 м. Это касается размеров заглубленной части котлована. По северному краю котлована с внешней стороны проходит ряд столбовых ямок. Как и в более поздних постройках, жилище имело продолжение и за пределами центрального котлована и эта часть была заглублена в материк на 0,2-0,3 м, то есть общая глубина жилища в материке достигала 0,6 м. В данном случае мы не можем узнать полные размеры котлована, т.к. сохранился только северный участок, менее заглубленный в материк. Его длина с севера на юг составляет около 3-3,5 м, что увеличивает общую длину сохранившейся части постройки до 8,5 м.

В заглубленной части котлована исследован очаг овальной в плане формы $(0,9 \mathrm{x} 0,55$ м). Дно очага округлое, стенки плавно поднимаются вверх. Глубина в материке - до 0, 2 м. Очаг полностью заполнен золистым грунтом. К северу от него располагались цепочкой четыре столбовые ямки, перекрытые слоем охры. Еще один очаг сохранился в периферийной части постройки. Он был более крупных размеров (диаметр 1,35 м), чем предыдущий, но по устройству, глубине и заполнению не отличался от него.

Под северной стенкой постройки сохранились две обширные $(1,1 \times 1,3$ м и 0,9х1,6 м) ямы, заполненные культурным слоем. Дно котлована посыпано красной охрой. Центральная часть котлована также перекрыта линзой светлого суглинка, под которой в заполнении котлована обнаружено парное неолитическое погребение $1^{6}$.

Остальные жилища нижнего слоя сохранились частично - это участки дна кот- 
лованов с хозяйственными ямами, очагами и столбовыми ямками. Сказать что-либо определенное о размерах жилищ по этим участкам сложно, за исключением северовосточного угла раскопа, где в квадратах 85-88 и частично 89 дно котлована жилища нижнего слоя по посыпке охрой прослеживается на протяжении почти 9 м по линии запад-восток (рис. 6, 3). На этом участке исследована одна из наиболее крупных двухкамерных ям (рис. 6, 4). Длина ямы 2,4 м, максимальная ширина 0,9 м, глубина - свыше 0,5 м. Заполнение ямы отличалось от нижнего культурного слоя более светлым цветом, что характерно для всех ям, связанных с нижним слоем. Следует отметить находку сегмента низких пропорций в заполнении ямы. Как и большинство других хозяйственных ям на стоянке, она устроена вдоль стенки котлована по дну жилища. Высота стенки котлована на данном участке около 0,2 м.

К нижнему слою также относится очаг в квадрате 6 (рис. 6, 5). Конструктивно он ничем не выделялся среди большинства других, но по периметру был окружен десятком столбовых ямок диаметром 0,1-0,3 м и глубиной до 0,35 м. Пол жилища вокруг этого очага также был неоднократно посыпан охрой.

Стоит упомянуть очаг такой же конструкции из сохранившегося участка дна жилища слоя 2 А в квадратах 70 и 72 . Он имеет округло-овальную форму (2,0x1,4 м), дно плавно понижается к центру, с северо-восточной стороны к нему вплотную примыкают шесть столбовых ямок. Очаг заполнен культурным слоем, в котором преобладает зола. Кроме этого, в заполнении найдены кости животных, обугленные и необугленные, фрагменты керамики, каменные орудия. В одной из ямок (диаметр 0,25 м, глубина 0,35 м), примыкающих к очагу, найден комплекс костяных орудий, поставленных в нее вертикально: фрагменты двух тупиков для волососгонки из лопаток животного, два землекопных орудия, проколка и обломок ребра крупного животного. По периметру очаговой ямы на расстоянии 0,05-0,5 м имелось около дюжины столбовых ямок 0,1-0,3 м в диаметре.

$$
* * *
$$

Таким образом, в раскоп на Варфоломеевской стоянке целиком не попало ни одно жилище, что не дает возможности установить их полные размеры. Если считать жилищами только наиболее заглубленные участки котлованов, то размеры их невелики: длина стенок колеблется в пределах 4-5 метров. Если же брать в расчет полные размеры котлованов, то площадь жилища существенно увеличивается. В таком случае общая ширина котлованов достигает 6-8 метров, а максимальная сохранившаяся длина - 11 метров (южные части котлованов размыты водохранилищем). Судя по сохранившимся участкам котлованов, жилища длинными сторонами были ориентированы по линии север-юг или северо-северо-запад - юго-юго-восток.

В плане котлованы жилищ-полуземлянок прямоугольные, с округлыми углами и не всегда ровными стенками. Глубина котлованов в материке могла достигать одного метра, как в жилище 2 слоя 2 А (рис. 3, 3).

Кровля жилищ опиралась на столбы. Столбовые ямки располагались вдоль края котлована с внешней стороны и по дну (по осевой или близкой к ней линиям). Диаметр столбовых ямок - от 0,1 до 0,35 м, глубина - от 0,05 до 0,55 м. Глубина зависела от диаметра ямки и уровня, с какого она была впущена в материк.

Высота стен землянки, вероятно, варьировалась в зависимости от глубины котлована. Возможно, столбы поддерживали бревенчатые балки, которые могли быть покрыты жердями, ветками и камышом, как это мы наблюдали на стенах жилища. Древесно-камышовая (предположительно) кровля неолитических построек, скорее всего, также покрывалась глиной. Как уже говорилось, на многих участках раскопа отмечены суглинистые прослойки, залегавшие в заполнении котлованов между культурными напластованиями (рис. $7,1,2$ ). Объяснять их наличие можно по-разному, 
так как заброшенные котлованы жилищ могли заполняться не только естественным затеканием грунта, но и использоваться населением в качестве мусорных ям. Но в любом случае стоит учитывать, что во всех котлованах есть эта светлая прослойка суглинка, не содержащая находок.

Жилые постройки были многокамерными или просто имели более заглубленную центральную часть. Во всех случаях полы в жилище располагались на разных уровнях. Это хорошо прослеживается по окрашенным охрой полам и золистым шлейфам очагов, опускающихся с верхнего уровня на нижний.

Внутренний интерьер представлен в первую очередь очагами. Очаги имеют простейшую конструкцию: округлый или овальный в плане, слегка заглублены (до 0,4 м) в материк и имеют пологие стенки. Если дном котлована жилища являлся более ранний культурный слой, то для очага насыпался 15-20-сантиметровый слой глины (рис. 7, 3). Часто вокруг очагов по периметру расположены столбовые ямки. Вероятно, это свидетельствует о существовании особого «светового фонаря», когда часть крыши жилища над очагом была приподнята, а в образовавшийся зазор проникал свет и выходил дым (рис. 6, 5). Очагов в жилище всегда несколько. Более сложная конструкция очага с сопряженными ямами в жилище 2 описана выше (рис. 3, 4).

Вплотную к стенкам котлованов в полу были устроены глубокие и обширные ямы. Заполнение их различалось. Большая часть ям содержала обычный культурный слой, а остальные можно назвать ямами-хранилищами. В них найдены в скоплениях зубы лошади с насечками, альчики, запасы кремня, орудия из кости, развалы сосудов (рис. 5,1 , $2 ; 6,3,4)$.

Полы жилища всегда покрывались слоем темно-красной охры (рис. 7, 4), что является уникальным случаем для построек неолитического времени в степной зоне юго-востока Европейской части России. Причем охра посыпалась на дно три-четыре раза, после очередного «загрязнения» пола. Это помогло в нескольких случаях проследить замену одного столба на другой, когда на дне котлована читался след от столбовой ямки, а после снятия слоя охры рядом с ним обнаруживался след от предыдущей. Подобные находки свидетельствуют не только о длительном функционировании жилища, но, вероятно, и о мощном перекрытии над ним.

Посыпка полов неолитических жилищ порошком охры в таких масштабах, как на Варфоломеевской стоянке, не находит аналогий среди других поселений Нижнего Поволжья. Использование охры, в том числе и для окрашивания полов, широко практиковалось в среде неолитического населения Европейского Севера ${ }^{7}$ и таежной зоны Зауралья и севера Западной Сибири ${ }^{8}$. Широкое применение охры в жилищах этих регионов объясняется не сакральными причинами, а чисто утилитарными, когда охра применялась для защиты от гниения деревянных конструкций 9 . Однако такое объяснение мало подходит для зоны сухих степей Заволжья, несмотря на все колебания климата в голоцене на территории рассматриваемого региона ${ }^{10}$.

О продолжительности функционирования жилищ, кроме регулярной посыпки полов охрой и замены опорных столбов, свидетельствует еще один факт. В некоторых очагах огонь поддерживался длительное время - непрерывная вертикальная колонка золы и углей иногда прослеживалась при раскопках на глубину до метра и более, то есть откладывался культурный слой, перестраивались жилища, а очаг оставался все тот же. Он только со временем мог слегка смещаться в стороны.

Таким образом, на Варфоломеевской стоянке исследованы жилища, функционировавшие на всем протяжении неолита и показавшие единую домостроительную традицию, характеризующую орловскую культуру. Следует также подчеркнуть тот факт, что жилища чрезвычайно плотно располагались на территории стоянки. Конечно, следует учесть, что исследованные 
постройки не функционировали все одновременно, но даже в восточной части раскопа, где исследованы только поздние постройки, они отделялись друг от друга незначительными по площади материковыми перемычками.

На поселении орловской культуры Орошаемое (раскопы Алгай 1 и Алгай 2) полученные к настоящему времени данные о жилищах подтверждают существование единой домостроительной традиции у орловского населения на протяжении неолита ${ }^{11}$.

Эта традиция значительно отличается от других культур, даже в пределах Нижневолжской культурной общности ${ }^{12}$. На юге Нижнего Поволжья, в Северном Прикаспии, наиболее информативно жилище на поселении Байбек каиршакско-тентексорской культуры ${ }^{13}$. Жилище на Байбеке не прямоугольное, как на Варфоломеевской стоянке, а округлое в плане, по размерам меньше варфоломеевских (14 кв. м). Нет здесь столбовых ямок, окраски полов охрой (хотя мелкие частички охры имеются), нескольких очагов и обширных ям под стенками. Но это также полуземлянка, и следует отметить наличие ямы рядом с очагом.

В другой культуре Нижневолжской неолитической общности - джангарской - жилища также овальные, небольшие (14-20 кв. м) и заглублены в материк до 0,3 м. В двух жилищах нижнего (третьего) слоя есть по два-три очага, хозяйственные ямы и даже небольшой участок дна, окрашенного охрой ${ }^{14}$. Столбовые ямки здесь, как и на Байбеке, отсутствуют, что может объясняться сооружением жилищ в рыхлом песчаном грунте, не сохраняющем относительно небольшие ямки, или просто отсутствием подходящего строительного материала, когда при сооружении жилища столбовые конструкции просто не использовались.

Жилища Байбека и Джангара сопоставимы по размерам с центральными, наиболее заглубленными в материк камерами варфоломеевских жилищ. Вполне возможно предположить, что и в данных случаях исследованные жилища представляют только центральную часть постройки, а окружающие их «галереи» просто не сохранились в рыхлых и перевеваемых ветрами песчаных грунтах, в отличие от суглинистых грунтов Варфоломеевской стоянки, где сохранность конструкций в материке несравненно выше.

В сопредельном регионе - лесостепном Среднем Поволжье - домостроительная традиция имеет еще большие различия, вызванные разными природно-климатическими условиями и хозяйственным укладом. Это особенно заметно при сравнении с постройками елшанской ранненеолитической культуры. Исследованные жилища елшанской культуры наземные, с каркасной конструкцией (Вьюново Озеро I) или слегка заглубленные с очагами и без (Утюж I, Имерка VII, Луговое III) и площадью 15-35 кв. м. Здесь нет следов углубленных долговременных сооружений ${ }^{15}$.

Ничего общего с варфоломеевскими жилищами не имеют производственная и жилая постройки неолитического поселения Дрониха I в лесостепи Среднего Дона ${ }^{16}$. Две постройки ранненеолитического времени на Верхнем Дону (Рыбное Озеро 2 и Васильевский Кордон 3) овальной формы были незначительно углублены в материк и, в отличие от варфоломеевских, имели сезонный характер ${ }^{17}$. Еще больше различий с жилищами лесной зоны, особенно это касается жилищ с переходами ${ }^{18}$.

Полученные данные о типе жилищ, их приблизительных размерах, технологии сооружения и элементах интерьера указывают на постоянное проживание там населения. Благоприятные климатические условия способствовали не только успешной охоте и рыболовству, но и оседлости населения на протяжении неолитической эпохи. В настоящее время можно констатировать тот факт, что домостроительная традиция орловской неолитической культуры, ставшая известной после исследования Варфоломеевской стоянки, пока не находит близких аналогий в степной зоне Европейской территории страны несмотря на схожий хозяйственный уклад населения степной зоны. 


\section{ПРИМЕЧАНИЯ}

${ }^{1}$ Юдин А.И. Варфоломеевская стоянка и неолит степного Поволжья. Саратов: изд-во СГУ. 2004, 200 с.; Юдин А.И., Выборнов А.А. Ранний неолит степного Поволжья // Археологические записки. Ростов-на-Дону, 2019. Вып.10. С. 99-109.

${ }^{2}$ Выборнов А.А., Юдин А.И., Кулькова М.А., Гослар Т., Посснерт Г., Филиппсен Б. Радиоуглеродные данные для хронологии неолита Нижнего Поволжья // Радиоуглеродная хронология неолита Восточной Европы в VII-III тыс. до н.э.: кол. моногр. / сост. Г.И. Зайцева, О.В. Лозовская, А.А. Выборнов, А.Н. Мазуркевич. Смоленск: Свиток, 2016. С. 62-73.

${ }^{3}$ Мамонтов В.И. Поздненеолитическая стоянка Орловка // СА. 1974, .№ 4. С. 257-258.

${ }^{4}$ Юдин А.И. Варфоломеевская стоянка и неолит степного Поволжья. Саратов: изд-во СГУ. 2004. Рис. 58, 3.

${ }^{5}$ Там же, рис. $54,4$.

${ }^{6}$ Юдин А.И. Неолитические погребения Варфоломеевской стоянки // Археология Восточно-Европейской степи. Саратов, 1991. Вып. 2. С. 3 - 14.

${ }^{7}$ Витенкова И.Ф. Эволюция жилых построек в финале неолита и энеолите Карелии // Труды Карельского научного центра РАН, 2012. № 4. C. 174-169.

${ }^{8}$ Усачева И.В., Адаев В.Н., Косинская Л.Л., Юдина E.A. Охра в жилищах каменного века таежной зоны Зауралья и Севера Западной Сибири: адаптивный аспект// Человек и Север: Антропология, археология, экология: Матер. всероссийской научн. конф. Тюмень: ФИЦ ТюмНЦ СО РАН, 2018. Вып. 4. С. 254-258. .

${ }_{9}$ Там же, с. 256-257.
10 Овчинников А.Ю., Выборнов А.А., Кулькова М.А., Занина О.Г., Лопатина Д.А., Дога Н.С., Юдин А.И., Алифанов В.М. Почвенно-экологические условия на нео-энеолитическом поселении Орошаемое в Нижнем Поволжье // Почвоведение. 2020 № 2. С. 165-177. С. 173-174.

${ }^{11}$ Юдин А.И. Жилища орловской неолитической культуры // Волго-Уральский регион от древности до средневековья: материалы VI Нижневолжской Международной археологической научной конференции. Волгоград: Изд-во ВолГУ, 2020. С. 23-25. Рис. 2.

${ }^{12}$ Юдин А.И. Нижневолжская культурная общность эпохи неолита: проблемы формирования, контактов и эволюции // II Городцовские чтения. М., 2005. Тр. ГИМ. Вып. 145. С. 7-17.

${ }^{13}$ Гречкина Т.Ю., Выборнов А.А., Лебедев Ю.С. Жилище ранненеолитической стоянки Байбек в Северном Прикаспии // КСИА, № 262. 2021. С. 142-155.

${ }^{14}$ Кольцов П.М. Мезолит и неолит Северо-Западного Прикаспия. Москва: Изд-во ГЖО «Воскресенье», 2005. С. 125-128. Рис. 36.

${ }^{15}$ Андреев К.М. Жилищные комплексы елшанской ранненеолитической культуры // Самарский научный вестник. 2020. Т. 9, № 3. С. 189-193.

${ }^{16}$ Синюк А.T. Население бассейна Дона в эпоху неолита. Воронеж: Изд-во ВГУ, 1986. С. 93-98. Рис. 17; 18.

${ }^{17}$ Смольянинов Р.А. Постройки эпохи раннего неолита на Верхнем Дону // Самарский научный вестник. 2016. № 1 (14). С. 72-76.

${ }^{18}$ Ставицкий B.B. К вопросу о реконструкции неолитических жилищ лесной зоны // Неолитические жилища. Материалы международного симпозиума. СПб., 2021. С. 35-36. 


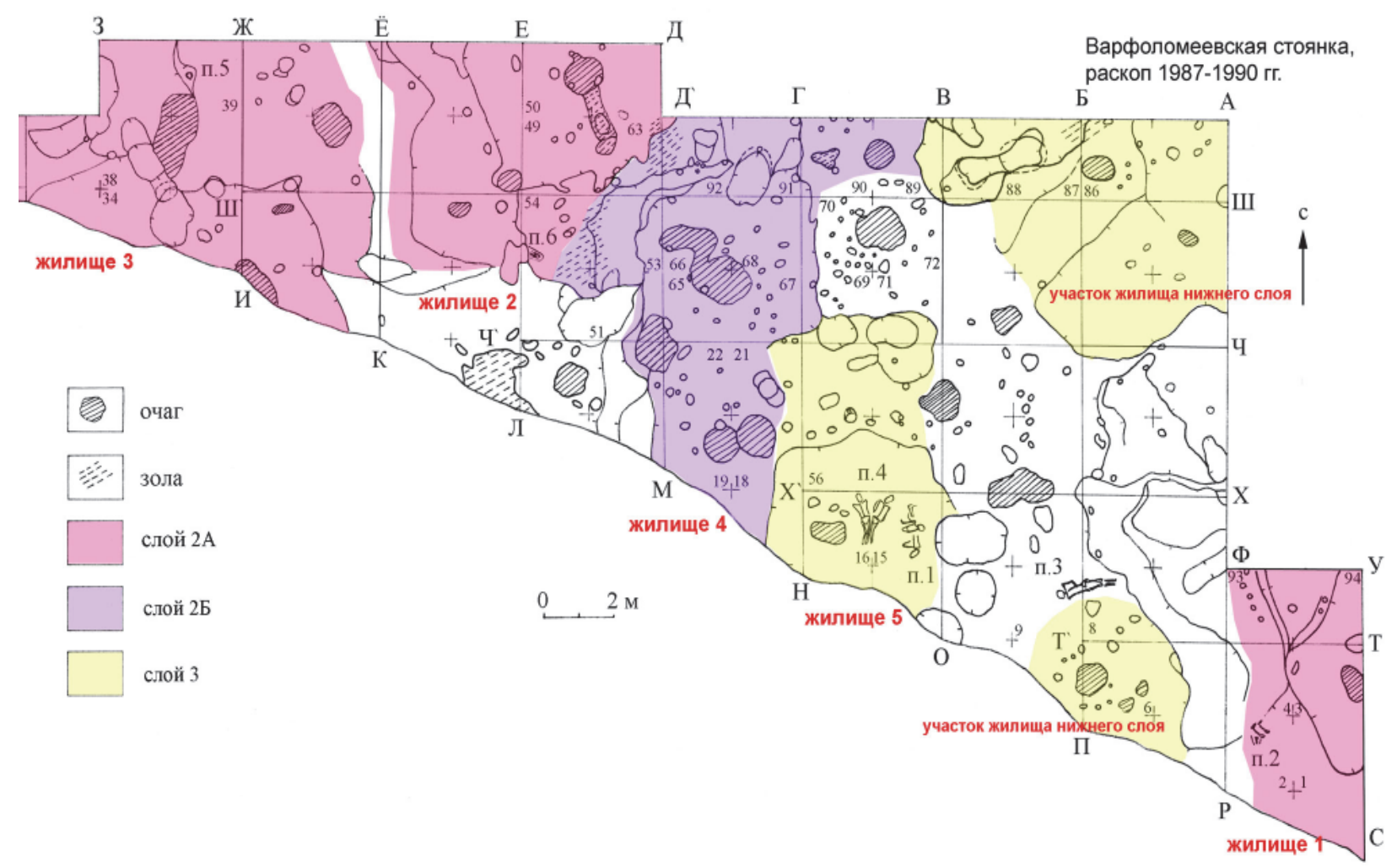

Рис. 1. Варфоломеевская стоянка. План раскопа 1987-1990 гг.

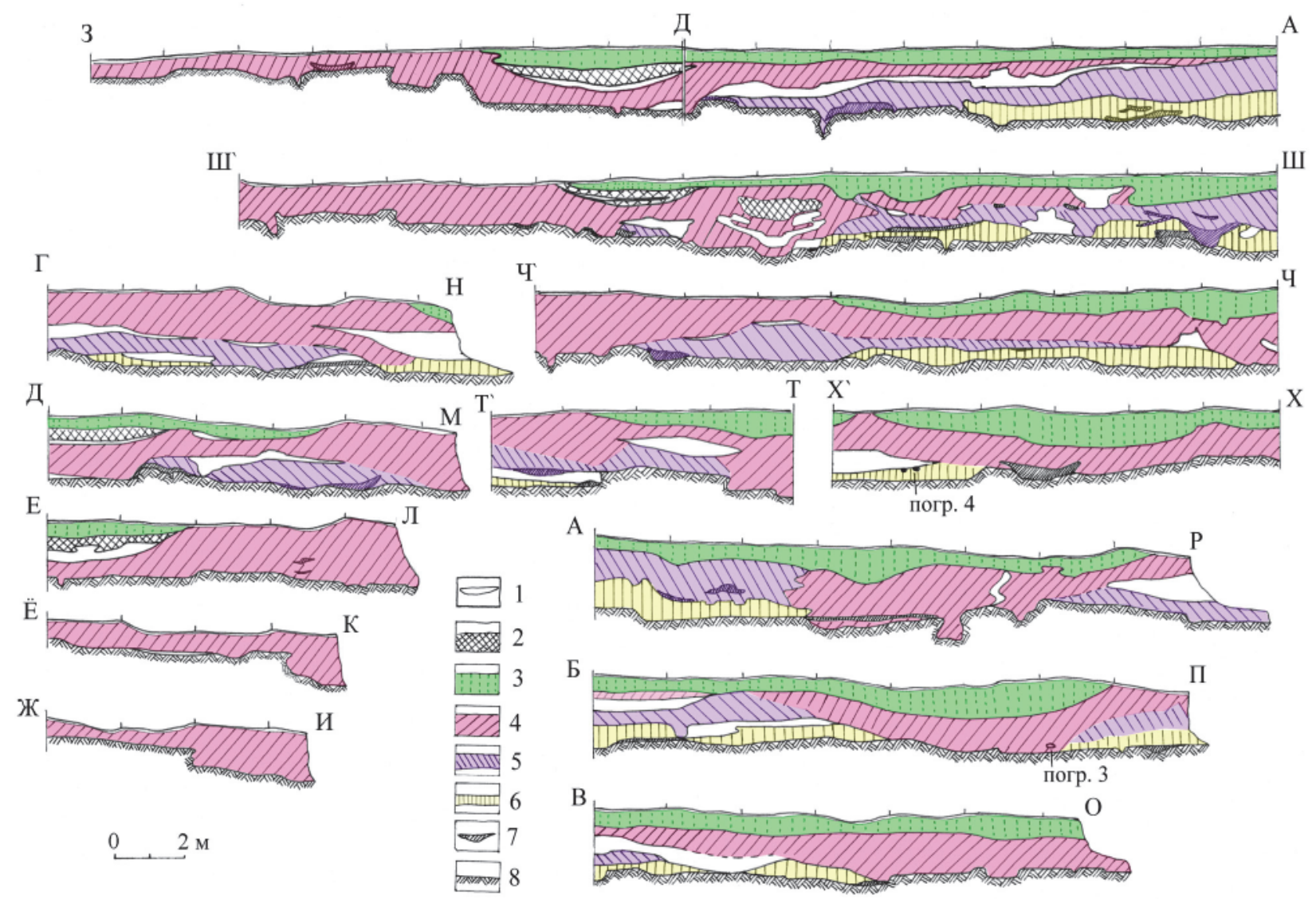

Рис. 2. Варфоломеевская стоянка. Стратиграфия раскопа 1987-1990 гг.

1 - светлый суглинок; 2 - культурный слой с примесью золы; 3 - верхний (1) культурный слой; 4 - слой $2 \mathrm{~A} ; 5$ - слой 2Б; 6 - нижний (3) культурный слой;

7 - золистое заполнение очагов; 8 - материк 


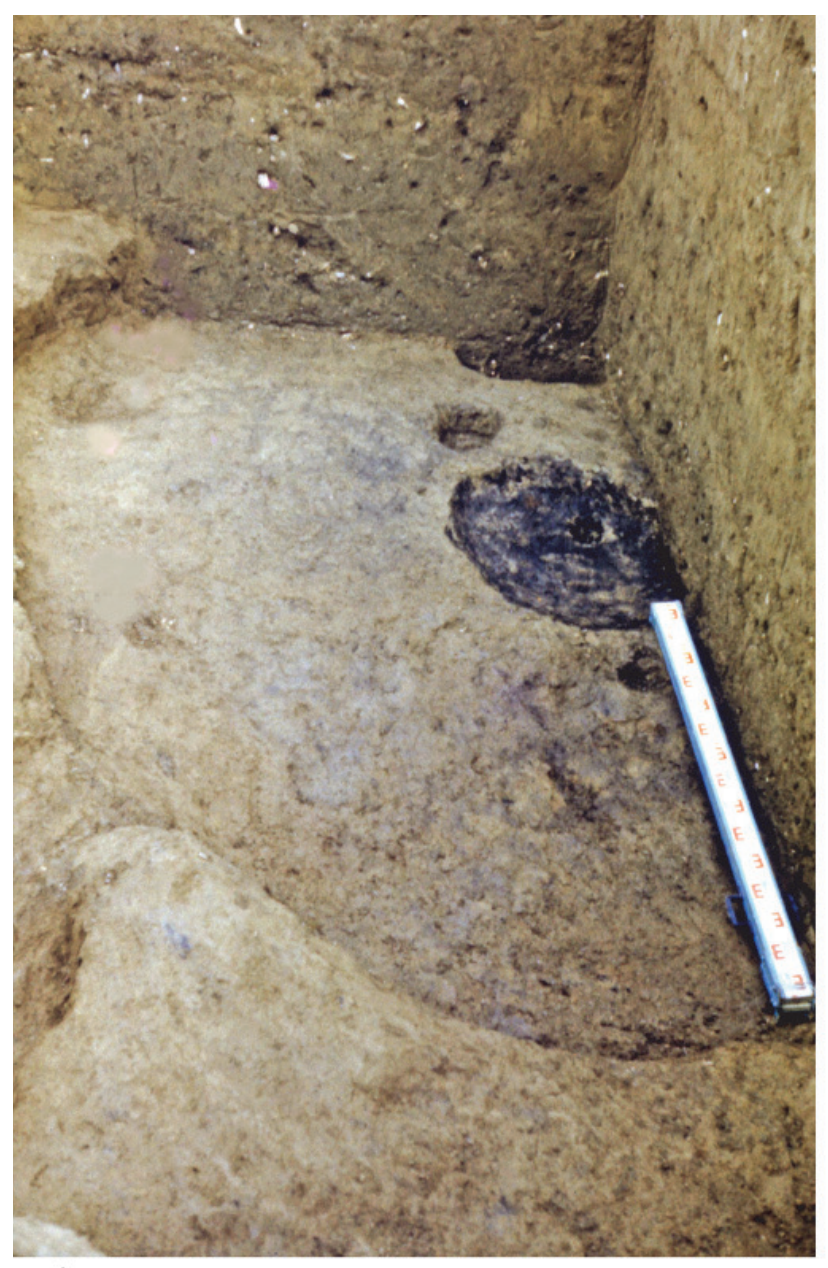

1
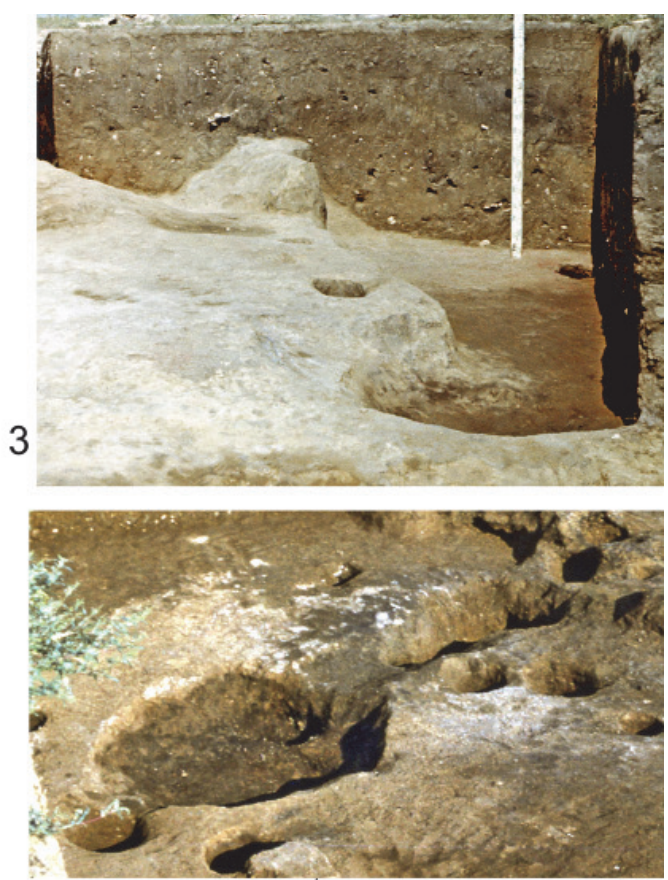

i.

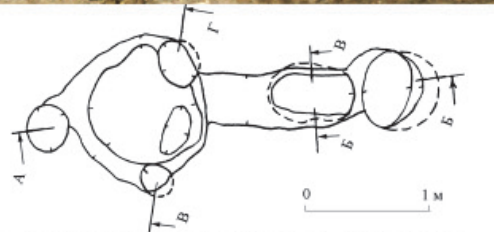

4

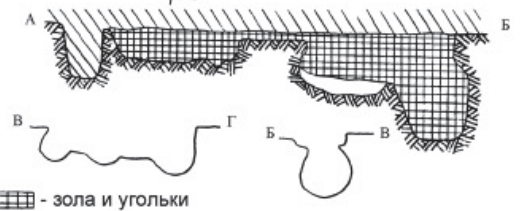

- зола и угольки

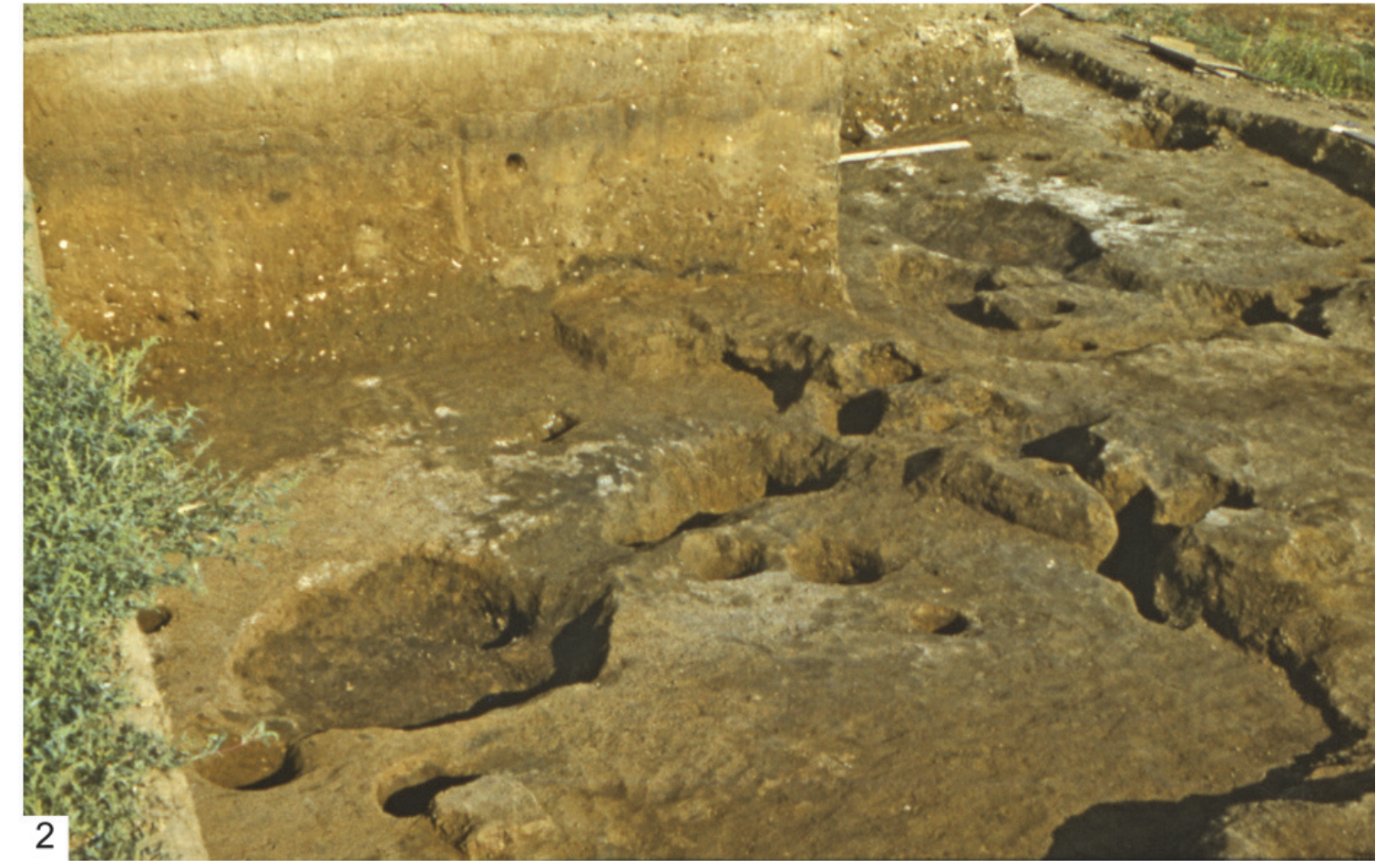

Рис. 3. Жилища Варфоломеевской стоянки.

1 - жилище 1 , слой 2А; 2 - жилище 2, заглубленная часть, раскопки 1988-89 гг.; 3 - жилище 2, юго-западный угол и стенка котлована, раскопки 1987 г.; 4 - центральный очаг в жилище 2 


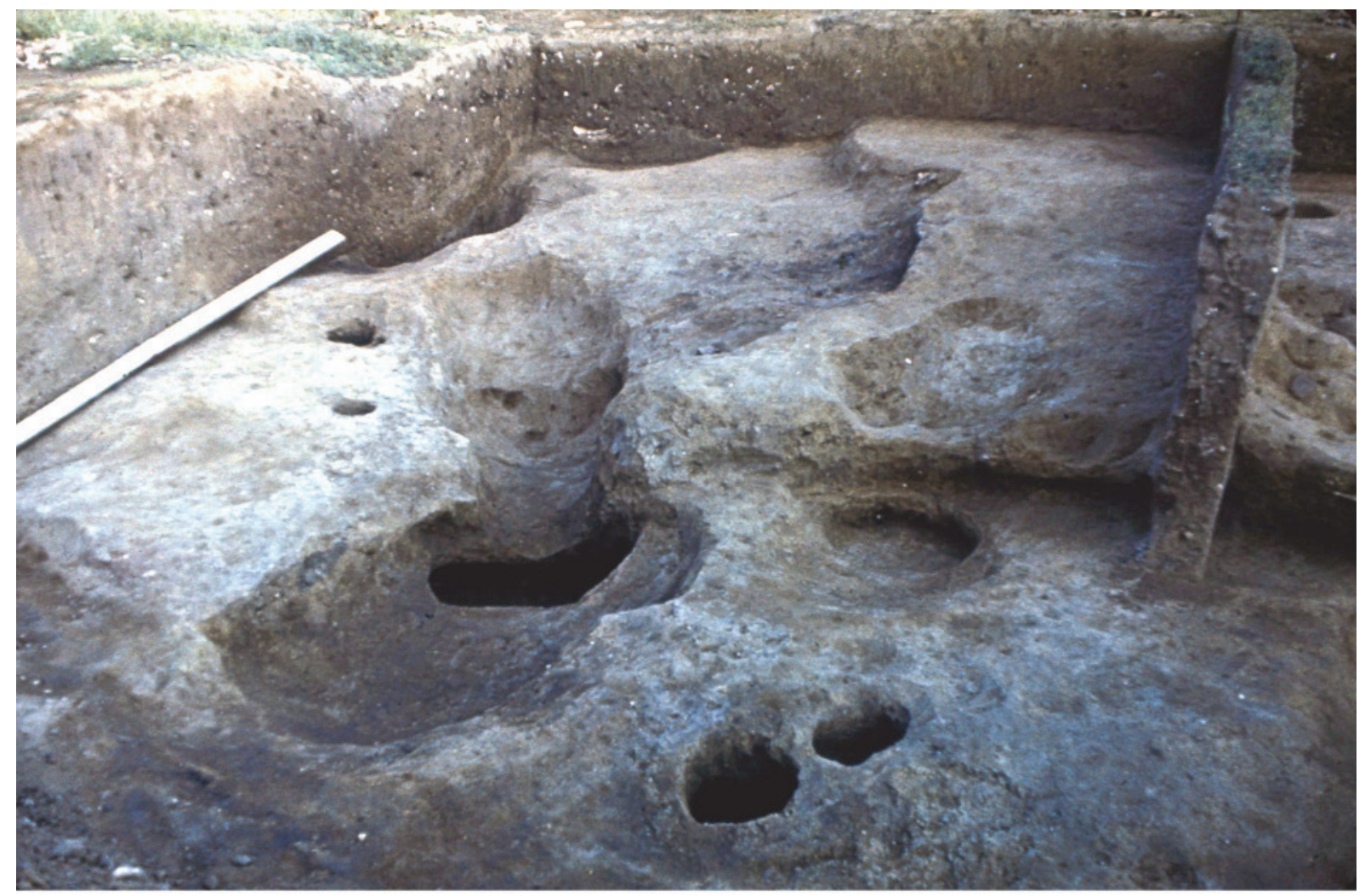

1

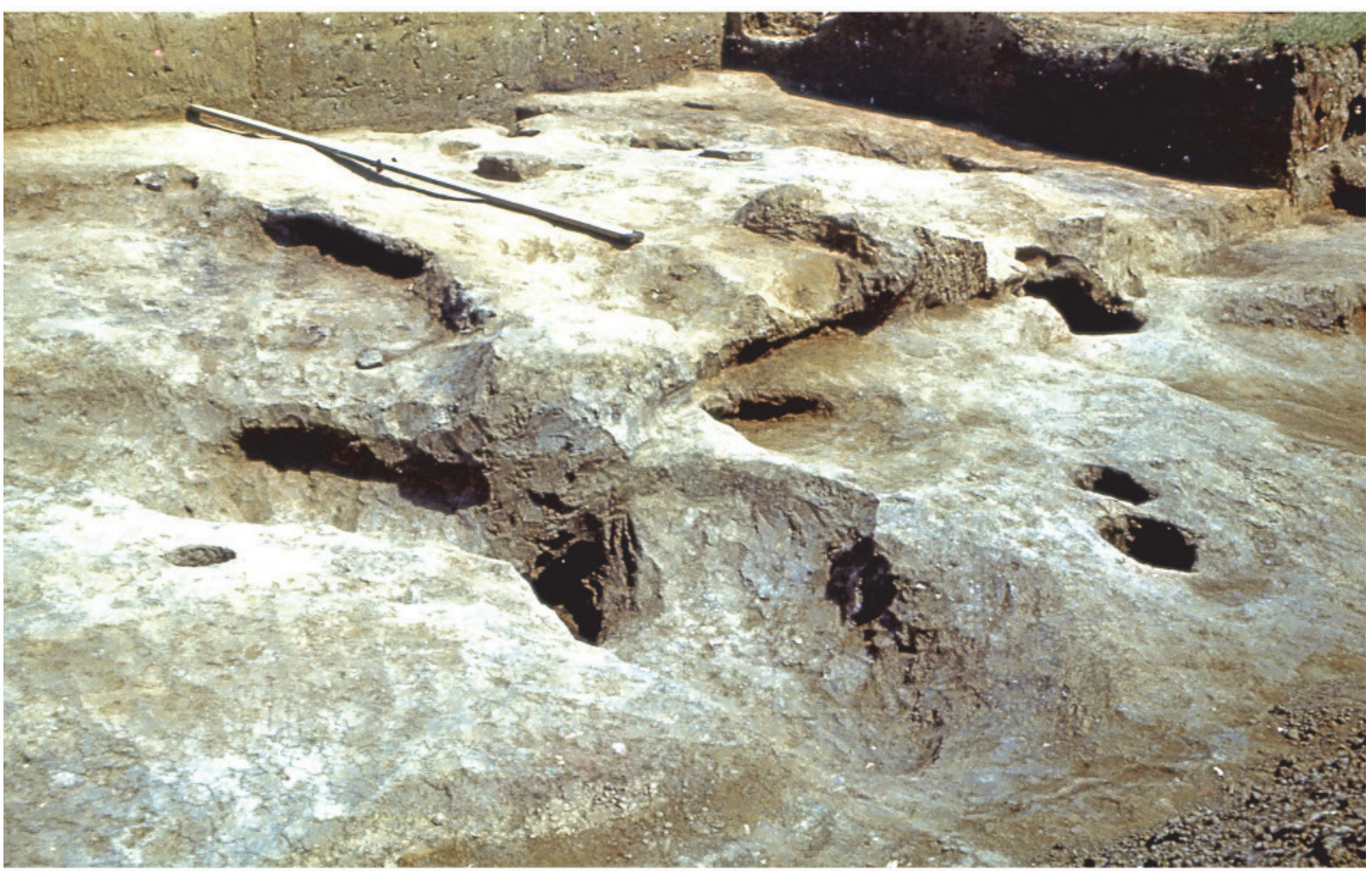
2

Рис. 4. Жилище 3.1 - вид с юго-юго-востока; 2 - вид с юго-запада 

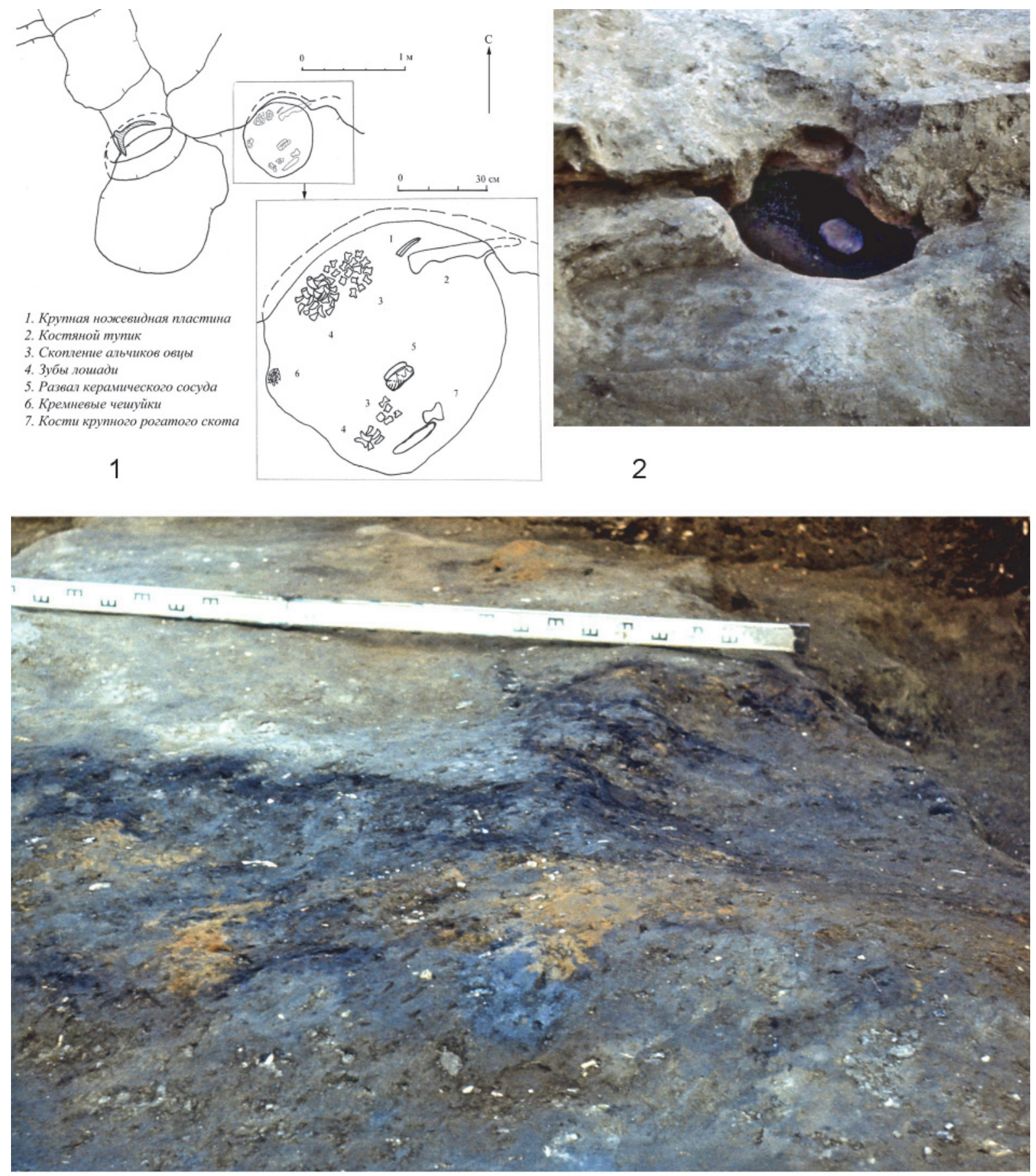

3

Рис. 5. Конструктивные элементы жилищ.

1, 2 - ямы под стенкой центрального котлована жилища 3; 3 - сгоревший угол жилища 4 до расчистки, вид с северо-запада 


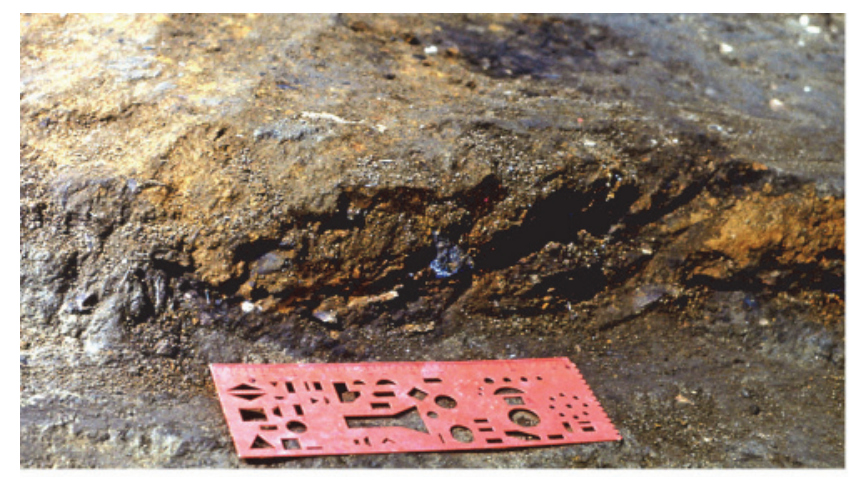

1

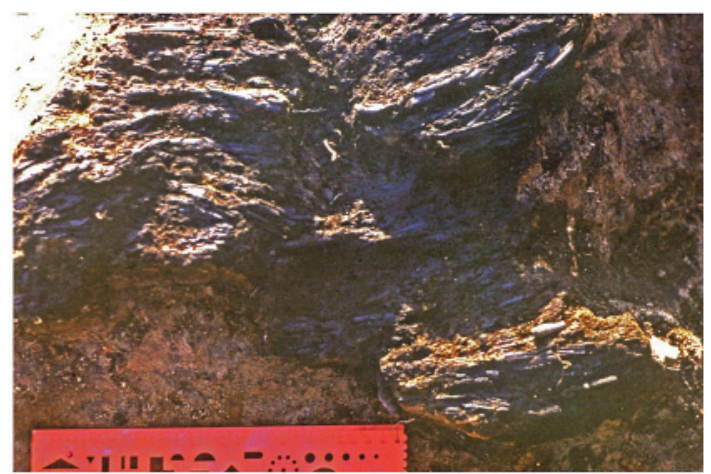

2
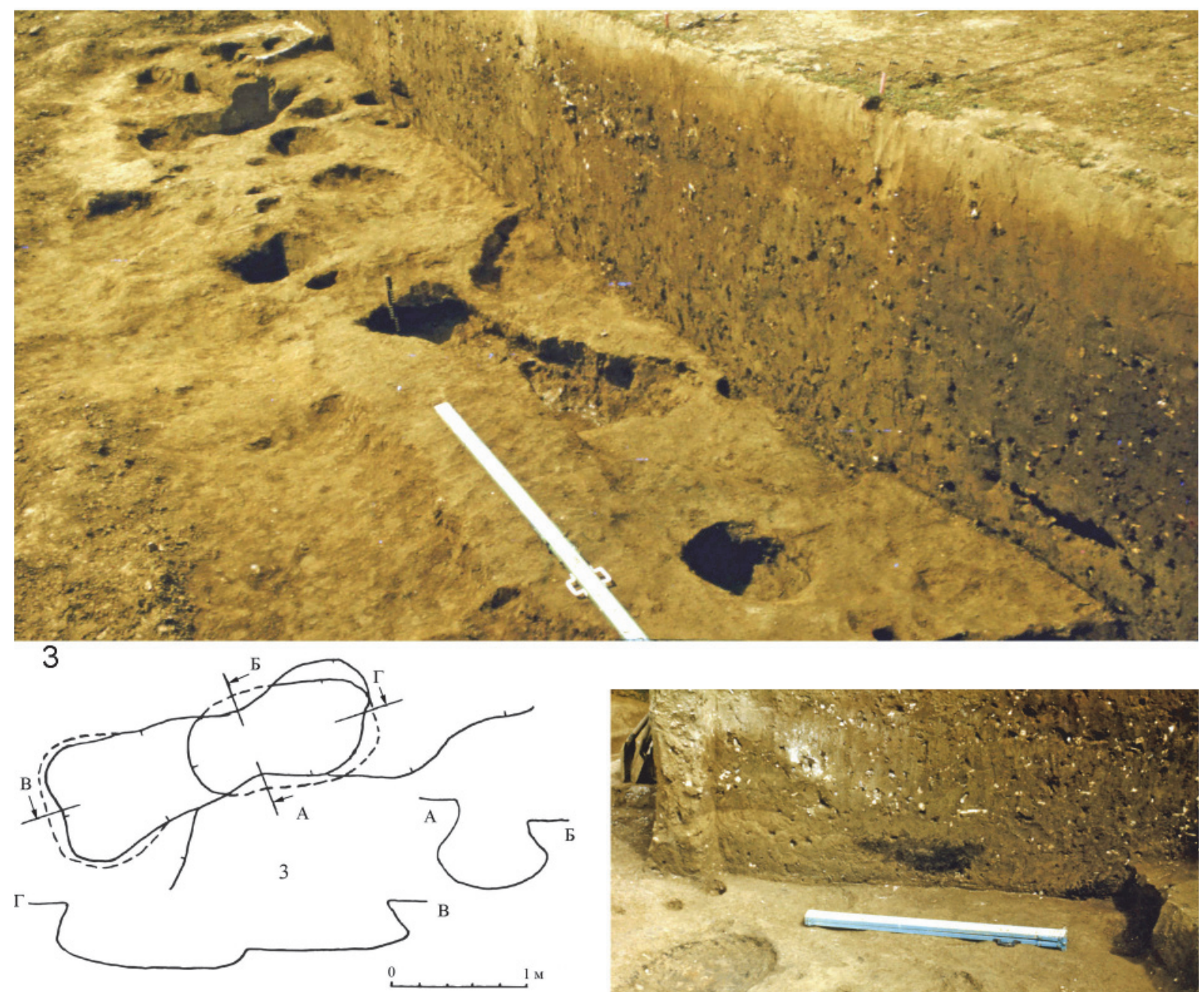

4

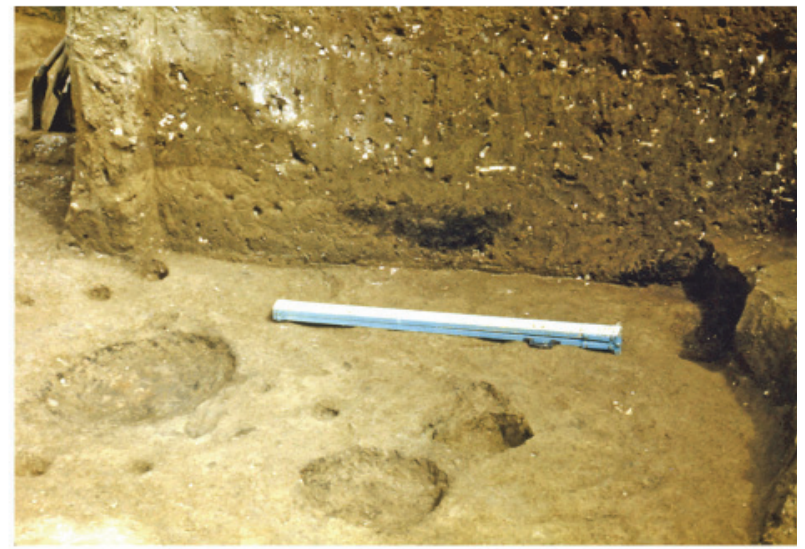

Рис. 6. Конструктивные элементы жилищ.

1 - разрез сгоревшей стены; 2 - сгоревший тростник в толще стены;

3 - участок дна котлована жилища нижнего слоя;

4 - план и разрез ямы с участка дна котлована нижнего слоя;

5 - очаги в квадрате 6 (нижний слой) 

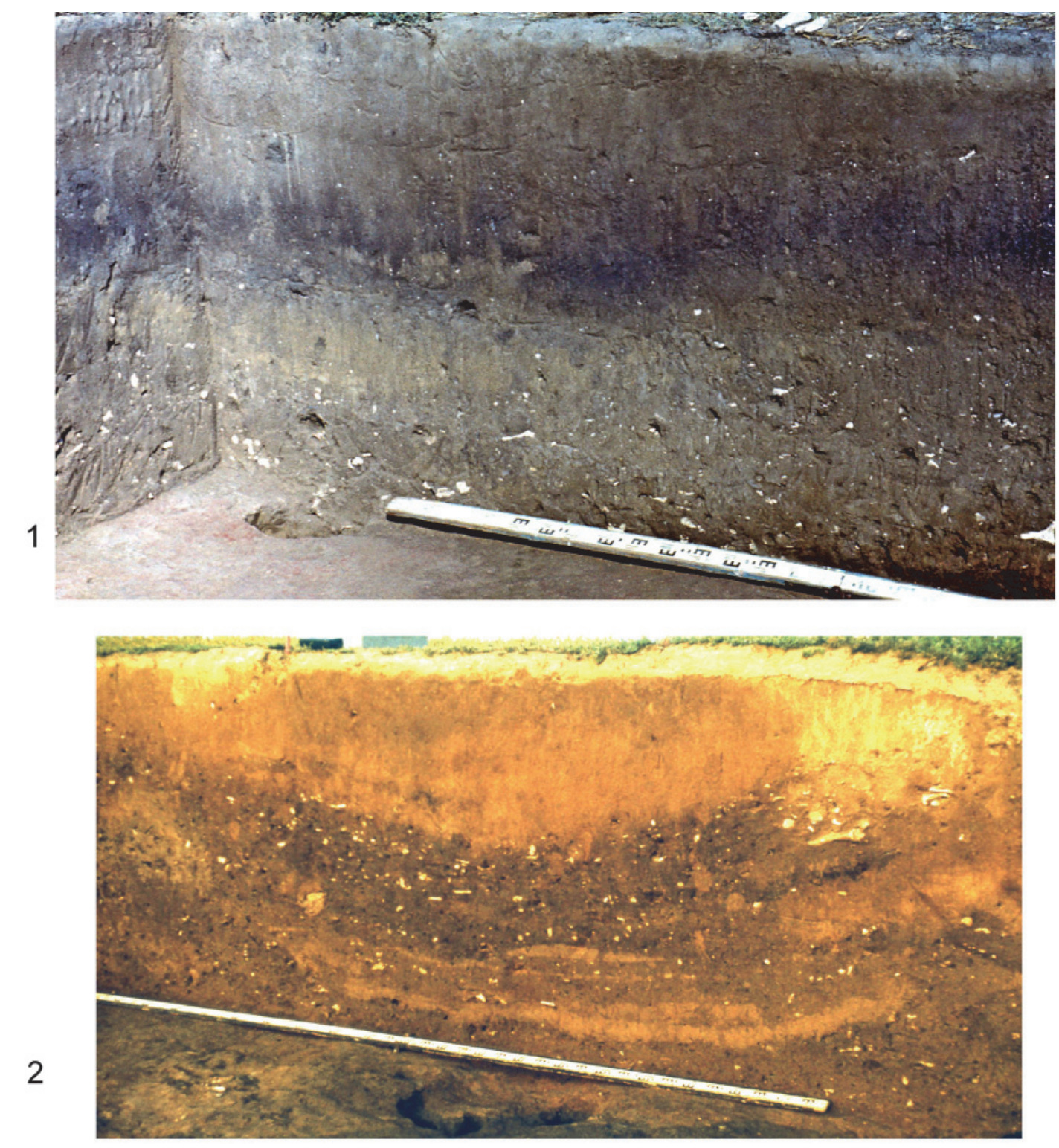

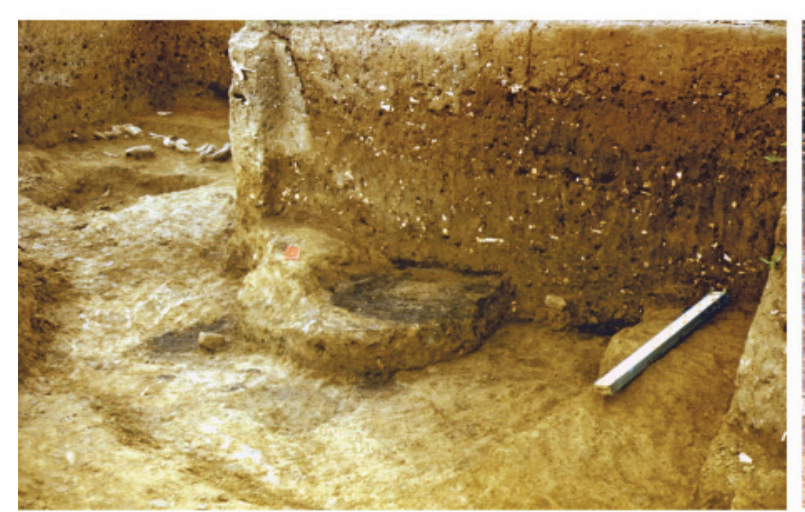

3

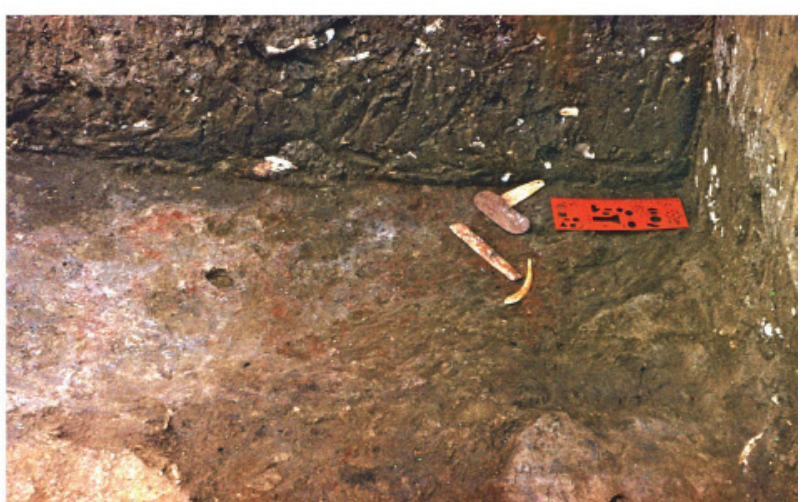

4

Рис. 7. Жилища стоянки.

1 - стратиграфия заполнения котлована жилища 2; 2 - заполнение котлована жилища слоя 2A; 3 - очаг в культурном слое; 4 - дно котлована, окрашенное охрой, и орудия для обработки керамики 


\title{
DWELLINGS OF THE VARFOLOMEEVKA NEOLITHIC SITE
}

\author{
(c) 2021 A.I. Yudin
}

\section{Research Center for the Preservation of Cultural Heritage, Saratov}

The article is devoted to the study of the nature of housing construction on the Varfolomeevka site of the Orlovka Neolithic culture of the steppe Volga region. The most complete data were obtained during the excavations of the Varfolomeevka site (late VII-VI thousand BC) on the Maly Uzen river. Later residential buildings overlapped and damaged the earlier ones, but a comparison of the planimography and stratigraphy made it possible to distribute them along chronological horizons and reconstruct the main characteristics of Neolithic buildings. Dwellings are represented by large semi-dugouts with several hearths, utility pits along the walls of the ditches, the location of floors at different levels, and dense building on the site. The dwellings had been functioning for a long time. This is confirmed by long-term foci with ash deposits of more than one meter on both monuments and traces of repair of support pillars at the Varfolomeevka site. It is established that there was a single stable tradition of housing construction at all stages of the Orlovka culture.

Keywords: Neolithic, Orlovka culture, dwelling, semi-dugout, hearth

DOI: 10.37313/2658-4816-2021-3-4-115-131

$\overline{\text { Alexander Yudin, Doctor of History, Deputy Director for }}$

Research.E-mail: aleyudin@yandex.ru 